\title{
RURAL AND URBAN LIFE FOR SARAWAK DAYAKS
}

\author{
Albertus ${ }^{1}$ \\ NARMAC (Natural Resource Management Collaboration) Institute, \\ Jalan Purnama, Gang Purnama 4 Nomor 22B, Pontianak. Handphone: 081351214702, \\ albertn89k@gmail.com \\ and \\ Mira Sophia Lubis ${ }^{2}$, \\ Urban Design and Sustainable Urban Planning, The Faculty of Engineering, Tanjungpura \\ University, Jalan Ahmad Yani, Pontianak. \\ Dikirim : 6 Maret 2016, Diterima setelah perbaikan : 16 Mei 2016
}

\begin{abstract}
The paper envisages rural and urban life of Sarawak Dayak by describing the ways in which the living spaces, job specialization and social interaction shaped them. The urban life promised attraction of good amenities such as university, economic development, transportation networking, health service, prosperity and livelihood improvement. Those trigger the flows of people and goods. Then, city faced serious problems such as traffic congestion, garbage, jobless, slum dwellers, squatter settlements, and social tension. To minimize the city's problems, it must be seen as organic order, when the correlative and expressive faculties are potent enough to maintain organic order, the problems can be handled. In this binary, a rural life is portrayed as mountainous area in which the villagers live in the longhouse and practice customary law. In this situation, the mechanism of life will be able to run independently because the village life is like mechanic which can be separated each other. The study refers to the description living spaces named rural and urban spaces, in which these two living spaces need one another. Longhouse and village became city for the inhabitants in the past, and nowadays, modern city become a place for livelihood to replace farming ground. Furthermore, the description of living spaces and the peoples, the factors which have the contribution to fade rural and urban distinction identified.
\end{abstract}

Key Words: Rural-Urban life, Sarawak Dayak, Living Space

\begin{abstract}
ABSTRAK
Makalah ini menggambarkan kehidupan kelompok masyarakat Dayak di Sarawak, yang tinggal di kawasan pedalaman dan perkotaan, dimana ruang hidup, spesifikasi pekerjaan dan interaksi sosial membentuk mereka. Kehidupan perkotaan menjanjikan fasilitas publik yang menjadi daya tarik, seperti universitas, perkembangan ekonomi, jaringan transportasi, pelayanan kesehatan, kesejahteraan dan perbaikan mata pencaharian. Hal ini memicu pergerakan arus manusia dan barang. Sebagai akibatnya, kota menghadapi berbagai masalah serius, seperti kemacetan lalulintas, sampah, pengangguran, pemukiman kumuh, dan ketegangan sosial. Untuk mengurangi masalah perkotaan maka kota harus dipandang sebagai sebuah organism yang saling berhubungan satu sama lain, ketika kemampuan hubungan dan ekspresif cukup kuat untuk memelihara susunan organ tersebut, maka masalah perkotaan bisa ditangani. Sebaliknya, kehidupan pedalaman digambarkan sebagai daerah pegunungan dimana penduduk desa tinggal di rumah panjang dan menerapkan adat istiadat. Dalam situasi seperti ini, mekanisme kehidupan akan berjalan secara bebas sebab kehidupan desa seperti
\end{abstract}


mesin yang bisa dipisahkan satu sama lain, tidak perlu saling tergantung. Kajian ini merujuk pada pengambaran ruang hidup yang disebut kota dan pedalaman, dimana kedua ruang tersebut bergantung satu sama lain. Di masa lampau rumah panjang dan desa menjadi kota bagi penghuninya, dan sekarang kota modern menjadi tempat mata pencaharian menggantikan tanah pertanian. Selanjutnya, gambaran tentang ruang hidup, masyarakat dan faktor faktor yang berkontribusi mengaburkan perbedaan antara kota dan desa diidentifikasi.

\section{INTRODUCTION}

This small research project was conducted in Sarawak, especially in the city of Kuching and its periphery. Kuching and its suburban areas recently became a significant attraction for national and international tourists due to the promotion of its rich social, cultural, and historical contexts. This research was also expanded to Miri because Miri is the second largest city in Sarawak. The focus of research was the indigenous peoples of Sarawak, better known as Dayak. In the colonial era, they were called Sea Dayak for Iban and Land Dayak for Bidayuh and Selako. The Land Dayak were described as docile, meek, weak, friendly, introverted, timid, and tender persons who spent most of their lives in the upper rivers and mountainous areas. The Sea Dayak, were described as extroverted, brave, cruel, and aggressive persons who practiced the bejalai (walk and adventure) tradition which was the symbol of the Borneo headhunter.

Sarawak region as a part of Borneo is much visited by the international tourists who are called 'Mat Salleh', a term used by Sarawakians for white western tourists from Europe and United States. "Malaysia Truly Asia" is the motto which is repeatedly broadcasted on international television to describe Malaysia as the example of real Asia. The motto of "Malaysia Truly Asia" is the expression of changing identity that directly indicates the changing of communities in social, cultural and historical contexts. Malaysia succeeded in developing its country as one example of modernized country among developing Asian countries in the shortest possible time.

The progress of Malaysia as truly Asia can be seen through the development and civilization of the cities, and its rapid population growth. In fact, the population growth of Malaysia is inseparable from the development and expansion of the cities, and the industrialization of the rural areas. The transformation of cities and their people is reflected in the changing identity of the communities. The Sarawak State Government realized that to regulate the city's growth and avoid population density, several main attractions of the city such as supermarkets, bus stations, government offices, public institutions, and universities must be built in the suburban areas and peripheries. For instance, the Institute of East Asian Studies (IEAS) of the University Malaysia Sarawak, the host institution to conduct this research, was built in Samarahan. The university used to be located in Kuching's city center. At IEAS, the researcher and research consultant carried out seminars, and used office space and the library for the research.

"Malaysia Truly Asia" is one vision of Malaysia's government. "Truly Asia" is the result of striving to make the vision become reality. It is a blend of social, cultural, and historical development in the Malaysian people. The aspects in becoming "Truly Asia" are the people, nature, and exotic social, cultural, and historical life. This research tried to examine the relationship between indigenous peoples (Dayak) as basically inland people, and their new environment in the city. The Dayak and their social, 
cultural and historical life will be elaborated on below.

Dayak is the collective name for the indigenous peoples of Borneo. In Sarawak, the Dayak consist of Iban, Bidayuh, and Selako. In the olden times, their way of life and related culture were regarded as primitive, old-fashioned, cruel, paganistic, backward, and revolving around headhunting practices. These prejudices caused them to experience torture, humiliation and harassment at the hands of outsiders. Such treatment, in turn, made them feel inferior, marginalized, indifferent, underestimated, and even aggressive. Moreover, being inland people, they had direct contact with nature. They consulted with and related to natural elements such as omens, the spirits of ancestors, and deities. These conditions enhanced 'a shared us feeling' among them as a consequence of having the same fate and destiny shaped by natural elements and bad treatment from outsiders.

The commencement of the Brooke era (1841-1941) provided opportunities for the Dayak to move from the rural to the urban areas. In the urban areas, the Dayak started to adjust to the new environment through self-reliance. It cannot be denied that the urban lifestyle had positive and negative influences on the Dayak's culture, local wisdom, and way of life.

To scrutinize the Dayak's identity and the possibility of its changing, some interviews were conducted and their results are presented here. Several theoretical perspectives from scholars quoted.

According to the United Nations Permanent Forum on Indigenous Issues, a modern understanding of the Indigenous Peoples should consider the following: (1) their self-identification as indigenous peoples at the individual level and their acceptance by the community as members; (2) their historical continuity with precolonial and/or pre-settler societies; (3) their strong link to territories and surrounding natural resources; (4) their distinct social, economic, or political systems; (5) their distinct language, culture, and beliefs; (6) their forming nondominant groups in society; and (7) their resolve to maintain and reproduce their ancestral environments and systems as distinctive peoples and communities. According to Benedict Kingsbury (1995, 23 ), the World Bank promulgated a new operational directive in September 1991 which states that "the terms indigenous peoples, indigenous ethnic minority, tribal groups, and scheduled tribes describe social groups with a social and cultural identity distinct from the dominant society that makes them vulnerable to being disadvantaged in the developing process. For the purpose of this directive, indigenous peoples is the term that will be used to refer to these groups." Based on the aforementioned criteria and definition, it goes without saying that the Dayak ethnic group can be considered Indigenous Peoples because all the criteria and the definitions stated by the UN are valid for them. For the sake of national security and development, the Malaysian government also provided for ethnic segregation in the Malaysian Constitution of 1957.

Just as ethnic segregation in Malaysia was permanently defined in the Malaysian Constitution of 1957, the constitution also mentioned the Indigenous Peoples of Sarawak and Sabah in article $161 \mathrm{~A}$ [6] and [7], and named them "bumiputera". This ethnic category was formulated to differentiate the indigenous peoples from the Chinese and Indians. In Peninsular Malaysia, bumiputera is applied to Malay and Native groups, whilst in Sarawak, the term is used for Malay, Sea Dayak (Iban), Land Dayak (Bidayuh and Selako), and upper river peoples which further consist of many subdivisions. Due to the ethnic segregation defined in the Malaysian Constitution of 1957, the status of indigenous people as Iban, Bidayuh, and Selako will still be embedded in their social life. 
There is no official definition of Dayak in Malaysia, anyway, we can say that a Dayak is someone born of a parent from the Dayak lineage (Selako, Bidayuh, and Iban); he or she speaks Dayak vernaculars, and adheres to Dayak customs and traditions. This category is suited for the three dimensions of ethnicity identified by Fisherman (1977) in Appel and Muysken $(1987,12)$ to be paternity, patrimony, and phenomenology.

The Iban group still consists of several subdivisions divided in accordance with the rivers where they dwell, such as Iban Batang Lupar, Iban Batang Rejang, Iban Skrang, etc. From a linguistic perspective, the Iban tribe is included in the Ibanik language family. Bidayuh is divided into four different ethnic dialect groups, as follows: Bukar Sadong dialect (Serian District), Biatah dialect (Kuching District), Singai/ Jagoi dialect (Bau District), and Selakau/Lara dialects (Lundu District), (Chang Pat Poh 1999, 19). In this paper, Bidayuh and Selako are distinguished based on the language they speak. Bidayuh members speak dialects from the Bidayuhik language family, while Selako members speak dialects like those of the Malayic language family.

A large concentration of Iban such as Sibu, Sarikei, Kenowit, and Kapit areas dwell along the Rejang River basin. Their early settlements were found in the Sri Aman and Betong divisions. The Bidayuh are mainly found in the Penrissen, Padawan, Serian, and Bau areas, whereas the Selako are mainly found in the Lundu area.

Being inland people, culture, livelihood, and way of seeing the world were determined by nature. All these aspects intertwined with one another. For example, in the Dayak's cultivation practices, all customs and traditions related to natural elements from the time of the land survey up until harvesting time, e.g., Gawai Batu (stone feast) for Iban, Naik Dango (harvest feast) for Selako. Sounds of birds were used to determine the location of ground farming and the schedule to clear the land. Krober (1963) in Maffi $(2005,601)$ said, "Cultures are rooted in nature, and therefore can't be completely understood except with reference to environmental or natural factors." In rural life, several aspects of nature directly formed Dayak's culture such as omens, dreams, rain at midday, a rainbow in the sky, and taboos. These aspects were able to trigger fear in the Dayaks who saw in them signs of calamity. Nonetheless, these elements were also able to predict the time for holding some activities like feasts, farming activities, hunting, and gathering. These aspects shaped the notion of how Dayak construed themselves.

In the rural areas, two environmental features are considered to have formed the social, cultural, and historical life of the Dayak: shifting cultivation and residency in a longhouse. Shifting cultivation was the main livelihood of Dayaks and also the core of the Dayak culture, due to the involvement of adat ceremonies based on natural elements. For instance, the Gawai Naik Dango (harvest feast among the Dayak Selako) and Gawai Batu (stone feast among the Dayak Iban), conducted annually after harvest time, indicated a sign of respect for the spirits and nature. In this farming method, Dayaks planted hill paddies with corn, cassava, and indigenous vegetables.

The longhouses were built as a fortress to protect the Dayak, especially the women and children, from enemy attack when headhunting practices among the Dayak were rampant in the past. The Dayak's enemies were the other Dayak sub-ethnic groups outside their community members. Thus, for instance, there were encounters between the Iban and Bidayuh groups. In addition, longhouses also became the centers of the socio-cultural activities (births, weddings, festive events, and funerals' ritual) of the inhabitants. As the center of the socio-cultural activities, 
longhouses became cities for Dayaks in the past. When a longhouse served as a Dayak city, every decision for the Dayak such as barter, laws, customs and traditions, and schedules to cultivate farmland and arrange the feasts would be determined in the longhouse.

In modern society, a city is a physical environment for rapid social changes where multicultural interactions happen. Staying in a city for the first time may be a challenge for a Dayak, though they prefer to live in this new living space. Having spent most of their lives in a rural area, Dayaks have to learn many things about city life such as job specification, urban people's different perceptions of time compared to the Dayak, meetings based on the appointment, and the differences in cultural behavior among those who live in a multicultural society. In order to keep their identity as Dayak, they need to be empowered in the field of culture and identity when dealing with the influences of city life. The pursuit of this sort of empowerment should be clearly addressed in the national education curriculum as early as the first year of school.

Research objectives consist of the description of the situation and characteristic of Kuching (including Lundu and Serian towns) and Miri cities, as follows, such as to describe the Selako, Bidayuh, and Iban cultures, their social situation and history during a specific period of time; to describe how the three communities feel about living in the city; and, to identify in the Iban, Bidayuh, and Selako communities their changing identities in the urban area (Kucing, Lundu, Serian, and Miri) due to the development of cities. This study tries to look at the changes in the Dayak identity as an interior people after having had intensive contact with the urban environment. The basic idea of this paper is to see how city life shapes and influences the Dayak's socio-culture and way of life. The expected contributions of city life to the Dayak community include: a new way of thinking, particularly their beginning to construe themselves as part of the wider community; and, how this new way of thinking enriches their life such that they maintain a great understanding of one another for the betterment of the community, and strengthen their awareness of their local knowledge and wisdom, for the sake of their own dignity, sovereignty and integrity.

\section{METHODOLOGY}

This research applied a qualitative method through observations and interviews that were supported by relevant theories. Since this study used a multi disciplinary approach, relevant theories from various scholars are elaborated on throughout the different sections of this research. In-depth interviews with informants were also encouraged. Additional data and information considered as primary data and information were obtained from various articles and books. The field findings were collected through random sampling. There were 100 persons interviewed during the field work in Kuching, Lundu, Serian, and Miri. Twenty percent were recorded, while $30 \%$ of the interviews were done during working hours, and $50 \%$ were investigated and interviewed in the traditional markets, which sold local vegetables, fruits, and food, such as the Sunday Market in Kuching, and traditional markets in Serian and Lundu. Most of the interviews were conducted candidly to maintain a natural atmosphere.

\section{RESULT AND DISCUSSION}

Sarawak measures 124,449 square kilometers. According to Mark Cleary and Peter Eaton $(1992,18)$, "Since the ancient 
time, the central spine of rugged mountain with dense, impenetrable, and steamy rainforest which covers the middle island of Borneo had become the boundary of nation-states, Kalimantan, Indonesia and Sarawak-Sabah, Malaysia." Brosius (1986, 175) said that "the forest and mountains were the repository for memories of past events."

The coming of Islam to Brunei in the $16^{\text {th }}$ century marked the commencement of the dominance of the Malay Kingdom in Sarawak. On 24 September, 1841, James Brooke was appointed Sarawak Governor and then assigned as Rajah. Subsequently, Brooke's family governed Sarawak for 100 years, from 1841 to 1941. On 1 July, 1946, Sarawak was proclaimed a British colony. Finally, on 16 September, 1963, Sarawak joined Malaya to form the nation of Malaysia (Tan Chung Lee 2006, 7-9).

The population of Sarawak by ethnic groups can be broken down as follows: Iban 713,421 (31\%), Malay 568,113 (23\%), Chinese 577,646 (27\%), Bidayuh 198,473 (8\%), Melanau 123,410 $(5 \%)$, and others $156,436(6 \%)$ for a total population of 2,354,048 persons (Department of Statistics, Malaysia 2011). Sarawak has its own blend of culture derived from the different ethnic groups. Indeed, it is home to 28 ethnic groups, each with its own distinct language, culture and lifestyle. The Ibans form the major ethnic group on this region; the Chinese who generally live in the cities are the second largest group, followed by the Malay, Bidayuh, Melanau, Selako and other native tribes of Sarawak called Upper River Peoples. The Malays are mainly concentrated along the coast.

\section{The City as a Place of Rapid Social Change}

A city is defined as a community whose members live closely together in a unified complex of buildings, often enclosed by wall; a community in which a significant portion of the population pursues its everyday activities inside the city, in nonagricultural occupations, (see: Irving $\mathrm{M}$ Zeitlin: 1984:334). Cities are also a kind of special environment as the source of social change. In city's environment, growth is so rapid and its energy so great that it changes its complexion almost daily, and with it the characters of mankind itself. Urbanization is defined as a process of growing population concentration whereby the proportion of the total population which is classified as urban is increasing (Lee, 1991:12). Thus, the city can influence and shape a particular character trait of the community that dwells in that city. Conversely, community members who reside within the city could also form the hallmark of the city. For example, in the Indonesian city of Yogyakarta, the majority of the population consists of students and humanists. Thus, the city is known as a city of students and a city of culture. Several cities in Bali are known as tourism objects because they are much visited by tourists.

City life shapes cultural behaviors such as how to dress, which language to use, and ways of interacting in the community. Besides that, city life also shapes the inhabitants' psyches. For instance, for the sake of privacy, houses in a city are often fenced. Cultural attributes such as traditional clothing and customs, symbols of adat, including a variety of performances for tourists and visitors, are a part of the process of changing identities that will be very interesting if examined at the level of social, cultural and historical contexts. Therefore we can say that cities are a place in which social, cultural and historical changes of human beings take place. The study of social change is concerned with the processes through which societies and cultures are transformed. Cities are characterized by high population density, diverse social strata, the specialization of jobs, and a consumer society that provides the 
promise of prosperity and livelihood improvement. The specialization of jobs in urban areas has established a pattern of complex relationships with the isolation of groups, depending on their job specialization and social status. This phenomenon tends to cause people with the same kinds of jobs to be more closely associated with one another. Due to the specialization of their jobs, people can easily change their social class.

Today, the main problems in urban areas are traffic congestion, flooding, garbage, disease, joblessness, slum dwellers, squatter settlements, and social tension. The increase in vehicles and population growth are not balanced with the increase in physical infrastructure such as roads, housing, and other facilities. This condition has been aggravated by limited job availability, which ultimately triggers unemployment and criminality.

In order to be sustainable, the modern city must heavily depend on the network system in the periphery, namely, the suburban areas, villages, or settlements in the vicinity. The network system consisting of economic forces, labor, education, and trade functions as a connective tissue that feeds the city through the network of commuting goods and people. No less important is that the farming ground applied modern science and technology must be built in and around the suburban, periphery, and the nearest areas from the city to feed the people in the city.

In many countries, the men who migrate to cities still become a great problem. The process of growing the urban population as a result of the movement of the rural people into the urban areas need to be handled wisely. According to Ridu $(2003,21)$ "What we need to do is to enhance the urbanization of rural life through rural-urban convergence characterized by towns, rural non-farmers, and fading rural urban distinction." Most of the Dayak's villages in Sarawak are provided with good transportation networks to cities that enable villagers to live conveniently as commuters. As commuters, the villagers can commute easily from village to the city and head back to their village again on the same day. In the village, they can work at their home to provide goods, handicrafts, local vegetables, etc. and bring the goods to the city in the morning; and then in the afternoon, they can be back again in their villages. This way of living and working should be encouraged for the Dayak, due to the scarcity of land in the city and expensive housing options.

\section{Kuching City}

"Kuching is derived from the mata kuching (cat's eye) - fruit tree (Nephelium nalarense)," so says Alice Yen Ho (2004, 10). This city is situated in the middle of Sarawak River which has a number of bridges built by the state to provide access to either side of the river, making it very convenient.

Kuching consists of two administrative areas administered by a Datuk Bandar, legally called "Mayor" in Kuching South and "Commissioner" in Kuching North. The Northern City of Kuching ever since the era of James Brooke who reigned from 1841-1868 became the administrative area. As James Brooke established houses and government buildings for his staff's offices and homes, this area was the center of Brooke's administrative kingdom. To develop his kingdom, Brooke encouraged migrant workers to come to Sarawak. They lived in many kampongs situated in the northern area. Meanwhile, since the early years of the city, the southern area was the center of business activities. This area is now better known as the city center.

Nowadays, the Dayak come to Kuching as commuters, or as temporary or permanent residents. As temporary residents, most of them live in rented rooms located on the second or third storey 
of buildings, although there are some employers who also provide rooms for their workers. These rooms are sealed and partitioned without any windows. A narrow alley stands between each of the rooms. There are three doors one needs to pass through to come to the rooms from downstairs. Each door has to be locked for security purposes. For the workers, these rooms are but a place in which to sleep. They are very similar to human cages. The rooms' building is the zone of the working people's homes. Meanwhile, permanent residents live in the residential zones and in single family dwellings. These are the zones of the high class.

To maintain the sustainability of urban life in Kuching, the government has encouraged the establishment of ruralurban interaction by enhancing the quality of physical infrastructure such as roads and bridges, water resources development, sewerage, the maintenance of high conservation areas for tourism purposes, and agricultural development. In the urban area, the main attractive amenities such as the university, tourist sites, bus stations, supermarkets, and traditional markets are built outside the city center. For Dayaks, this situation is a blessing in disguise because they can access these amenities easily. For instance, they can go to the university from their village, and buy food, clothing, and household needs by commuting. This set-up accelerates social transformation and helps to erase the difference between rural and urban areas.

\section{Lundu Town}

The town of Lundu is surrounded by rivers, mountains and beaches. It became well known due to the attraction of those natural features. Since long ago the Kayan River has been a transportation artery for the people of Lundu to reach the hinterlands. The totem animal in the river is named 'ikan lundu', or 'lundu fish', and thus the area surrounding Lundu got its name.
This town lies between the Gunung Gading National Park and the Kayan River in the West of Sarawak. Gunung Gading National Park is famous because of the world's largest flower named rafflessia therefore this park is mainly used as a conservation zone. The attractive beaches in Lundu, Siar and Pandan beaches, and the people have made the Lundu area become one of the tourism objects in Sarawak. Lundu is a satellite town of Kuching which is located in Southwest Sarawak, at the border of Sambas District, West Kalimantan, Indonesia. From Kuching to Lundu it's about $90 \mathrm{~km}$, a distance one can reach in one hour by car.

This sleepy up-country town is the nearest town from the Dayak Selako's settlements. It is also the nearest place where the Selako are able to experience city life and intensive social interaction with outsiders. Most of the Dayak Selako commute to Lundu to sell their goods and forest produce. The local government provided a place for the Selako to sell local fruits and vegetables to the outsiders. This place became a hub of social interaction between the Selako people and outsiders.

\section{Serian Town}

In Serian, durian fruit is very familiar because most of the durian fruit in Sarawak derives from the rural Serian area. Durian has become the town of Serian's claim to fame. Serian Town is located at the Sanggau District Border, West Kalimantan, Indonesia. It is about 65 $\mathrm{km}$ from Kuching. Therefore, It can be reached in a half-hour or one hour by vehicles from Kuching city center. Serian is also a satellite town of Kuching. This town has become the most important place for the Bidayuh to interact. The town is very well connected to its rich hinterland, both by road and by river. As a satellite town, Serian has the potential to become the commuters' zones for their exposure to urban expansion. 
Based on the Yearbook of Statistics Sarawak 2011, the Serian district population was 90,763 , of which about $65 \%$ were Bidayuh and the rest consist of Chinese, Iban, Malay and India.

\section{Miri City}

Miri is located near the beach. The term "Miri" was derived from the name of Miri's natives, known as "Miriek". Europeans inadvertently changed the name Miriek to Miri. Miri's history is closely related to the history of the petroleum industry in Sarawak. On 10 August 1910, the Anglo Saxon Petroleum Company found oil in Canada Hill, overlooking the small fishing village of Miri. "At the time of the spudding in of Well No.1, Miri consisted of about 20 scattered houses and two Chinese shops" (Harper 1972, 24).

In the mid-1920s, Miri became the administrative center of the Miri and Baram regions. In the 1970 s, Miri was also the center of a major timber industry. Baram River, the second largest river in Sarawak, became the transport artery that linked inland forests to the coastal ports, thereby facilitating the conveyance of humans and timber. Owing to the support from these two main resources, Miri grew from a fishing village into one of the modern cosmopolitan cities in Sarawak within a short period.

Today, Miri, with an area of 977.43 square $\mathrm{km}$, is inhabited by several ethnic groups. The population by ethnic groups is as follows: Iban 90,649; Chinese 77,183; Malay 45,884; and other native ethnic groups, as many as 54,584 people (2010 census).

\section{Who are the Indigenous Dayak Peoples?}

Who are the indigenous Dayak people? What information do we use to categorize the Dayak? How have their territories formed their identity? In the past, the notion of the Dayak as backward, aggressive, fierce, cruel, ruffian, poor, stupid, uncivilized, pagan, drunken and head-hunting (Gomes 2007, 1) stigmatized them. As a result, Dayaks were marginalized, humiliated, and ignorant in all aspects of life. They had to struggle for their dignity, sovereignty, and integrity, and their quality of life was relatively low. In mid 1980, one of the prominent Dayak figures in West Borneo said, "If it was possible for me to fire myself as a Dayak, I would like to fire myself; but I cannot do that. Therefore, I have to empower myself so that the other ethnic groups will respect me as a human being." The Dayak history of being colonized, marginalized, manipulated, and humiliated by the Malay Sultanate ultimately led to the increase in their sense of kinship and solidarity. This, in turn created ' $\boldsymbol{a}$ shared us feeling', a feeling that they had the same fate and destiny which united them as one group, the Dayak. Aside from their cultural values, Dayaks also have a shared belief system and attitudes derived from natural elements. In the past, these shared beliefs were able to trigger fear and anxiety among them. Recently, many Dayaks from the younger generation did not allow themselves to be dictated to by these natural elements. Dayaks who had been to the city started to realize that their fear did not have a strong basis. They also witnessed how their forefathers feared such animals (certain birds, crocodiles, insects etc), which, in the city, were stored in the museum. Still, some Dayak members from the older generations continued to allow these natural elements to influence their belief systems.

\section{Dayak Selako}

Based on their language differences, the discussion on Selako and Bidayuh speakers is separated in this paper. According to several linguists, Dayak Selako members speak one of the dialects belonging to the Malayic language family, while the Bidayuh speak 
Bidayuhic \{(see Hudson $(1970,1978)$ and Collins (1999a, 1999b, 1999c) in Albertus (2003)\}. Language has strong dimensions that differentiate human identities. Fishman \{1977 in Appel and Muysken $(1987,13)\}$ stated "Language is the recorder of paternity, the expresser of patrimony and the carrier of phenomenology." As the recorder of paternity, language is able to pass on values, ways of life, and core cultures from forefathers to their descendants. It influences culture and thought. As the expresser of patrimony, language becomes a means of communication to express feelings and cultural practices, which facilitates the legacy of learning new values. As the carrier of phenomenology, language provides meaning to the culture and values inherited from the forefathers.

The starting point of the Selako's migration to Lundu area was from the Sajingan area, Sambas region, West Kalimantan. Schneider $(1974,195)$ stated that "The migration occurred in two waves: the Year 1830, Selako Gajekng who settled in Kampung Sedemak and around it, and the Year 1871 Selako Sangkuku' who settled in Kampung Biawak, Pueh and around it."

According to Nek Dewa, the informant from Sajingan village, "A group of persons in Dayak Selako community who can apply the customs, tradition, and customary law is usually more respected in their community because they were considered as having the responsibility to regulate the relationship between man and man, man and nature, and man with God. This group was called Salako Gajekng and the rest of the group is Salako Sangkuku." This group represented the Selako community in general. It seems that the Selako community leaders try to make the segregation based on caste to their community members as Gajekng and Sangkuku'. e longhouse (Rumah Bantang) of Selako people, was the center of their culture. It was associated with socio- cultural activities such as rituals and festive events.

During the reign of James Brooke as Rajah of Sarawak from 1841-1868, the Dayak Selako still conducted barter of their forest produce to purchase their households goods, as noted by Henriette (2008, 119): "Dayak chief with a number of his people come to Kuching to pay their rice tax, or purchase clothes, tobacco, gongs, gunpowder, whatever the bazaar possessed which they valued, to exchange for those things, they brought with them beeswax, dammar, honey, or rattan."

However, from 1960 to 1970 , the Dayak Selako planted palm oil, pepper, and rubber trees which provided a steady source of cash. Palm oil, pepper and rubber plantations were monoculture plantations because other vegetation could not be allowed to grow in the same area. Monoculture plantations for getting cash made it necessary for the barter system of the past to be replaced by the currency trading system.

The Bidayuh population in the Lundu region is around 12,034 (2010 census). This figure classified the Selako and the Bidayuh as one group. In 1970, Schneider (1974) recorded the population of Selako members to be 4,207 persons, which showed that in 40 years, the Selako community increased twofold.

\section{Dayak Iban}

The Iban moved from West Kalimantan to Sarawak as early as 1540 . They entered Sarawak by way of the lowlying Kapuas watershed between Batang Lupar and Batang Ai'. After the 1880s, the Iban populated the coastal region toward Miri (Samuel 2005, 42).

Iban people are familiar with the myth of Keling (the god of adventure and warfare) and Raja Berani (the King of Bravery). Keling and Raja Berani are the spirits of Iban to move and to walk (bejalai). Bejalai is an Iban tradition which is allegedly used as a driving force 
for the Iban to become the most aggressive people in Sarawak and the most interested in expansion. Bejalai means "walking", which was the way the Iban looked for farming ground, hunting, and gathering spaces. To it is attributed the Iban's spread to the whole Sarawak region within the shortest possible time.

Two aspects led to the emergence of Iban customs and traditions in shifting cultivation. First, the Iban believed that the forest and land are always inhabited by invisible creatures (the spirits of their ancestors and deities). Therefore, they should ask permission from these spirits/deities before clearing the land. Secondly, the Iban also believed that rice paddies have a soul or spirit; therefore, respect and gratitude toward the spirits should take place in the form of a feast, for instance, one of the feasts was a stone feast (Gawai Batu). Gomes (2007, 48), wrote "Gawai Batu takes place before the farming operations begin, and is in honour of Pulang Gana (the god of the land), who lives in the bowels of the earth, and has the power to make the land fruitful or unfruitful."

James Brooke who reigns from 1841-1868 encouraged the Iban who spread at the rural Sarawak to move to Kuching for the position of "Sarawak Rangers". The reason behind this was that James Brooke wanted to get the protection of the Iban, especially after the insurrection conducted by the Chinese gold miners in Bau in 1857. After that, the movement of the Iban to Kuching mostly happened due to the rubber economy which peaked in the 1900s especially when the first and second world war needed rubber commodity for industry. However, from 1947 to 1980 , the increase in the number of Iban members that moved from the villages to the cities was relatively very small because city life did not support the Iban's farming livelihood. Based on official statistics, in 1947 the Iban in urban areas comprised just $0.9 \%$, while in 1980 city dwellers were just $4.8 \%$ of the total Iban population (Department of Statistics Kuching in James Masing 1988, 57).

As time passed, the Iban learned the market mechanisms of working and selling their goods. Presumably, city life appeared more promising than staying at the longhouse. As the number of well educated Ibans increased in the city, many of them got decent jobs, conducted business activities, and obtained employment with a fixed salary.

The main reason for preferring life in Kuching was that everything was available, such as adequate food, lots of ways to earn money, medical services, and education. The close proximity between the villages and Kuching was also an important reason for the Iban to come to Kuching, either as daily commuters or residents.

Ibans with permanent jobs in Kuching chose to live outside the urban center in the suburban areas (commuters' zones), such as Tabuan Dayak, Sekama, and Sekandis. Nowadays, there are also some Iban in Kuching, among them prominent figures during the early days of Sarawak's independence. These are rich families who own hotels, supermarkets, oil palm plantations, etc. In Kuching, the Iban are divided into three social ranks: low class, middle class, and high class. Unfortunately, however, their incomes are not known. Most Iban choose to commute from the village to the city to do business, due to the proximity of the villages to the city.

\section{Dayak Bidayuh}

The Bidayuh people also originated from West Kalimantan, Indonesia. According to Nais $(1983,54)$ in Albertus $(2003,2)$ ''Dayuh' itself means far-inland or interior area. Bidayuh means having the elements of Dayuh in custom, culture, language, prestige, etc." Meanwhile, Geddes $(1954,6)$ said that "Bidayuh' means people of the interior". From these 
discourses, we can make one conclusion: that 'Bidayuh' is a person or group of persons who live in the interior.

Robert Jacob Ridu $(2003,16)$ stated that "Many writers and adventurers described Bidayuh as introverted, meek, docile, weak, friendly, and tender persons. They spent most of their lifetime in the upper rivers, headwaters, and mountainous areas." The Bidayuh are also a religious society. They believe in deities who live in the uplands and forest areas, such as, 'Tampa Raiyuh' (creator) (Geddes 1954, 25), 'Dervata' (from dewata of the Hindu deity) (Roth 1968, 7), 'Jewata' (from dewata of the Hindu deity) (Gould 1909, 38), 'Topah' (supreme being), etc. It is very possible that the presence of Bidayuh people in the hills and upper rivers was also motivated by a religious attitude, which is embedded in the Bidayuh people. Today, many Bidayuh people are converts to Christianity due to the fact that during the Brooke era (1841-1941), many missionaries came to their villages to introduce Christian values.

The Bidayuh believe that rice paddies have a soul or spirit. Patrick Rigep Nuek $(2005,9)$ wrote "The Bidayuh treat rice with respect, for fear the next harvest would be a poor one. They respect rice as if it had a life and soul, Ieng sumuk babai is the name of the soul of rice."

Nowadays, many Bidayuh live in the city, either as residents (permanent or temporary) or as commuters. Kuching residents commute, as well, though differently than a real commuter. They commute simply because they want to visit their family members in the village and for recreational purposes. Bidayuh commuters from the rural areas come on certain days to Kuching to sell their crops and farm produce. In Kuching, the government has set up a place for villagers to sell their crops, a traditional market which is famously known as the "Sunday Market". Every weekend, the Sunday Market is full of people from various backgrounds selling a variety of foods, forest produce, and handicrafts.

Bidayuh members who live as residents of Kuching are divided into two categories. One consists of those who have lived in Kuching for a long time and hold permanent jobs, e.g., teachers, lecturers, police officers, civil servants in governmental agencies and politics, midwives, nurses and doctors in hospitals, and security officers. The second group is made up of temporary residents. This group mostly consists of the younger generation, those who have just arrived in Kuching and have already gotten jobs but still do not have houses. For a while, they lease houses or rooms available in Kuching.

\section{How Dayaks Feel About Living in the City}

In the region of Kuching (including the towns of Serian and Lundu) and Miri, the Dayak could be divided into three groups. First would be the group that has the status of permanent residents in the city. The second group would consist of Dayaks who are temporary residents, while the third would be the commuters.

In general, permanent residents have a permanent job in the city, or have second and third generation descendants living in the city. They are able to adjust well to city life but their ties with their own homeland remain strong. Alim Mideh, a Bidayuh Dayak from Serikin, said, "In my opinion, Kuching is a better place to live in because all amenities needed such as education, health, and the market are available. Nowadays, I stay in Kuching. Anyway, I also still head back regularly to my village because most of my family members still live there. Besides that, my village is able to be reached from Kuching in just one hour by car."

When I asked about the influence of the city on the young generation of the 
Bidayuh, a prominent Bidayuh member, Patau Rubis, said, "The young generation of Bidayuh who live in the city are different from the Bidayuh in the village who still respect their parents and cultural values, and are still trustworthy. The young Bidayuh in the city do not respect local wisdom anymore. This is not a matter of changing identity, but is just a social disease due to the city's influences."

The second Dayak community group consists of temporary residents. This group usually includes young Dayak people who have already graduated from college or high school, or villagers who seek jobs in the city. This group mostly stays in the zone of the housing for workers to have easy access to their jobs. Their homes are in several storey buildings which provide rooms for rent in the second or third floor/storey. The function of the rooms is to provide a place to sleep. Roffina, an Iban girl from Miri said, "If I had a choice where to stay and work, I would choose to stay in the village rather than in this city. Living in this city is expensive, but I live in Miri because there is a job in this city; anyway, when I get older or start receiving a pension, I'll go back to my village again."

Midi Jonek, a Bidayuh who always commutes to Kuching said, "Nowadays, I am able to survive and live comfortably in the city because the roads and bridges reach the rural areas as well, so I can move from my village to Kuching in just 30 to 60 minutes. In Kuching I have a house, although to live in the city is a better choice for personal reasons, especially because you gain access to better education, job opportunities, and a career. I can assure you that my children will get better education and health." He added, "Recently, I experienced having no boundary between rural and urban any longer. I usually bring my laptop to my village from where I can access the internet 24 hours a day. Therefore, good transportation and information technology fades the gap between rural and urban areas."

As soon as they experience the process of transitioning to city life, Dayaks almost never practice their cultural traditions any longer. But this condition never changes their identity as Dayak members because they are an ethnic majority, and there is strict ethnic segregation in Malaysia which separates citizens into different ethnic group categories.

\section{CLOSING}

Living spaces of the men identified as rural and urban areas explained aforementioned above, for sure determine the life quality of the people including Dayak people. After moving from the village to the city, several aspects of their life such as way of life, culture, and social interaction slowly but surely changed. In rural areas, several influences such as the nature, culture, habit, paradigm, and theirus feeling which embedded in their mind created them as the indigenous people. Anyway, when these rural peoples move to the city, it took time to adjust themselves with the city life. In order to be sustainable living in the city, they must empower and develop themselves to meet the living standard of the city life. The young Dayak generation prefers to stay in the city because the city provides adequate living and working accommodations compared with the villages. They are ready to face every problems related to the city life in order to stay in the city simply because they city promise a better livelihood, better amenities, and better future for them. Anyway, as the attractive living space, city need to be sustainable, therefore they need to be designed and developed physically and culturally healthy. The development of farming ground based on the modern farming technology must be build in around the city such as in the suburban, periphery, and the nearest areas. The 
availability and quality of transportation and communication amenities from village to the city determine the energy of the city life, in which the people able to commute to sell their goods and back again at the same day, or they can become temporary resident for the sake of their business. Good roads, universities, health care services, and communication facilities will minimize the flow of people in the city. The architecture and city planner have absorbed the meaning of organic order process that city is like cell structure which cannot be separated, it is not independence. The people, the space, the networks of the city are really like cell structure which depend on one another to survive. The Dayak as the rural people, when moved to the city must be empower themselves based on self-reliance to adjust themselves with the city life.

\section{CONCLUSION}

In recent years, the urbanization and modernization of the rural areas, and the industrialization of natural resources through development programs provided the Dayak opportunities to interact with the outside world beyond their own community members. In Sarawak, transportation and communication networks connect all places and humans across the region. All areas gradually approximate urban areas.

In Kuching, the improvement of physical infrastructure such as roads, bridges, and storage facilities; water resources development including drainage, sewerage, river conservation and communication systems; social infrastructure such as medical facilities which consist of hospitals, dispensaries, maternity and health centers; educational components of infrastructure consisting of primary, secondary and technical schools, vocational schools and universities; as well as electricity, water supply, community centers, and security services have become the main attractions of city life. To a certain extent, these developments are also expected to reach the rural areas a condition that has the potential to reduce the differences between urban and rural areas.

Population growth due to urbanization has caused certain areas which were originally rural zones to turn into developing zones of the city. There is a tendency in Kuching for the city center to expand its area by invading the outer areas. For the Dayak people, especially those who now live in the city permanently and have disconnected themselves or are less related to their original homeland in the rural areas this progress has become a blessing in disguise. It has given them the opportunity to revitalize their own roots and basic identity as Dayaks, which have already faded due to the influence of modernization in the city. For commuters, this condition potentially improves their quality of life due to the increase in business activities. The temporary residents have also started to try harder to improve their qualifications by empowering themselves through formal education, as stated by Peter Minos (2003, 103) "Good formal education is our savior from economic backwardness and poverty and a vital vehicle for our advancement and progress."

Dayaks depending on the amount of preparation they have been given for the city living. The well-educated men and women regard the city as the place for a better life.. Meanwhile, Dayaks who do not get sufficient preparation will turn out to be menial workers with low salaries for whom city life will be a burden. City life will aggravate their inherited local values and wisdom acquired from the village.

The language spoken also has an important role in the identity of Dayaks. While the common language in the city is the Sarawak Malay language, Dayaks still use their vernacular when they get together by themselves. The use of the Sarawak Malay language will never disappear 
because the Malaysian government has determined the Malay language as the national identity of the Malaysian people.

There are many similarities among the three Dayak ethnic groups (Selako, Iban and Bidayuh). One similarity is how they practice egalitarian principles based on their self-confidence to show that they are able to do everything themselves without any help from outsiders. This indicates that all Dayaks are supposedly equal. These egalitarian principles are reflected in the movement of Dayaks from rural to urban areas, as discussed earlier.

\section{RECOMMENDATION}

Cities are the source of social changes, growth is so rapid and changes its complexion almost daily. City life shapes cultural behaviors such as how to dress, language-use, and ways of interacting, and the inhabitants' psyches. It provides the promise of prosperity and good livelihood. Those are the sources of flowing the people and goods from rural area to the cities. These will cause traffic congestion, flooding, garbage, disease, joblessness, slum dwellers, squatter settlements, criminality, and social tension. Anyway, the process of growing the urban population as a result of flowing rural people into the urban areas need to be handled wisely.

For the sake of sustainability, the city must depend on the network system with rural areas such as the suburban, villages, or settlements in the vicinity. The network system consists of economic forces, labor, education, and trade functions to feed the city life should be encouraged through the development of network of commuting goods and people. That's why, the government needs to enhance the urbanization of rural life through rural-urban convergence characterized by towns, rural non-farmers, and enhancing the buildings of public amenities outside the cities.
Good transportation networks from villages to cities will enable villagers to live conveniently as commuters and they also can enjoy city life from their own homeland in their villages. The good condition of the streets and communication system enable the villagers work at their home to provide goods, handicrafts, local vegetables and sell the goods to the city in the morning, in the afternoon they can be back again in their villages. This way of living and working should be encouraged for the Dayak, because the land and houses in the city are expensive.

\section{BIBLIOGRAPHY}

Albertus. 2003. Klasifikasi Varian Tengon Dalam Rumpun Bidayuhik (Borneo Barat): Tesis yang dikemukakan untuk memperoleh Ijazah Sarjana Persuratan Melayu. Bangi: Institute Alam dan Tamadun Melayu, Universiti Kebangsaan Malaysia.

Albertus, et al. 2008. Mozaik Dayak, Keberagaman Subsuku dan Bahasa Dayak di Kalimantan Barat. Pontianak: Penerbit Institute Dayakologi.

Appel, Rene' and Muysken, Pieter. 1987. Language contact and bilingualism. London: Edward Arnold.

Brosius, J. Peter. 1986. River, forest and mountain: The Penan gang landscape. Sarawak Museum Journal, XXXVI: 173-84.

Chin, S.C. 1986. Do shifting cultivators deforest. In Proceedings of the Conference on Forest Resources Crisis in the Third World 223: 231. Penang: Sahabat Alam Malaysia.

Cleary, Mark and Peter Eaton. 1992. Borneo, change and development. Singapore: Oxford University Press.

Department of Statistics Malaysia, Negeri Sarawak. 2011. Yearbook of Statistics Sarawak. 
Gomes, Edwin H. 2007. The sea-Dyaks of Borneo. Kota Kinabalu: Opus Publications.

Harper, G.C. 1972. The Miri field 19101972. The Sarawak Museum Journal Vol.XX No 40-4, January December 1972: 21:30.

Halim, DK. 2008. Psikologi Lingkungan Perkotaan. Jakarta: Penerbit Bumi Aksara.

Harriette McDougall. 2008. Sketches of our life at Sarawak. London: Society for Promoting Christian Knowledge, Northumberland Avenue, Charing Cross, W.C.; 43 Queen Victoria Street, E.C.; 26, ST. George's Place Hyde Park Corner, S.W.

Irving, Zeitling M. 1984. The social condition of humanity: An introduction to sociology. Second edition. New York: Oxford University Press.

Kingsbury, Benedict. 1995. Indigenous peoples as an international legal concept. In Indigenous peoples of Asia, ed. R.H. Barnes, Andrew Gray, and Benedict Kingsbury, 13-34. Michigan: The Association for Asian Studies, Inc. 1 Lane Hall, University of Michigan.

Lee, Goh Ban. 1991. Urban planning in Malaysia - History, Assumptions and Issues. Petaling Jaya Selangor Darul Ehsan: Tempo Publishing (M) SDN BHD.

Lee, Tan Chung. 2006. Journey Through Sarawak: A Pictorial Guide to the Land of the Dayaks. Singapore: Marshall Cavendish Editions.

Masing, James. 1988. The role of resettlement in rural development. In Development in Sarawak: Historical and contemporary perspectives, ed. R.A. Cramb and R.H.W. Reece, 57-

67. Victoria, Australia: Morphet Press Pty. Ltd, Centre of Southeast Asian Studies Monash University (copyright).

Maffi, Luisa. 2005. Linguistic, cultural and biological diversity. Terralingua,
Salt Spring Island, British Columbia V8K2N6,

Canada.www.annualreview.org/doi/p df/10.1146/annualrev.anthropo.34.081 804.120437.

Patrick, Rigep Nuek. 2005. A Dayak Bidayuh community rituals, ceremonies and festivals. Kuching: Lee Miing Press Sdn. Bhd.

Pat Foh, Chang. 1999. Legends and history of Sarawak. Kuching: Lee Ming Press Co.Department of Statistics Malaysia, Sarawak.

Peter, Kedit. 1988. Bejalai in Sarawak: In Historical and contemporary perspectives, (ed.) R.A. Cramb and R.H.W. Reece, 145-155. Victoria, Australia: Morphet Press Pty, Centre of Southeast Asian Studies Monash University (copyright).

Peter, Minos. 2003. Culture and economic progress: The Bidayuh experience. In Creating a new Bidayuh identity, ed. James Dawos Mamit, Ahi A. Sarok, and Nicholas Amin, 95-114. Kuching: Dayak Bidayuh National Association (DBNA).

Ridu, Robert Jacob. 2003. Reflections of the past and capacity building towards the $21^{\text {st }}$ century. In Creating a new Bidayuh identity, ed. James Dawos Mamit, Ahi A. Sarok, and Nicholas Amin, 15-24. Kuching: Dayak Bidayuh National Association (DBNA).

Saarinen, Eliel. 1943. The city: Its growth, its decay, its future. New York: Reinhold Publishing Corporation.

Samuel, Anthony K. 2005. Contemporary migration among Dayak Iban in Sarawak. Kuching: Masgraphics Service.

Schneider, William Martin. 1974. Social organization of the Selako Dayak of Borneo. A dissertation submitted to the faculty of the University of Carolina at Chapel Hill in partial fulfillment of the requirements for the degree of Doctor of Philosophy in the Department of Anthropology. 
Sothi Rachagan, S. 1993. Ketetapan konstitusi dan undang undang yang mengatur Orang Asli. In Suku Asli dan Pembangunan di Asia Tenggara, 161-177. Jakarta: Yayasan Obor Indonesia.

United Nations. 1 November 2010. United Nations Permanent Forum on Indigenous

Issues.www.un.org/esa/soedev/unpfli/ documents/5 session factsheet.pdf.

Yen Ho, Alice. 2004. Old Kuching. New York: Oxford University Press.

Yearbook of Statistics Sarawak. November 2011. Department of Statistics Malaysia Sarawak. 